\title{
HAND-ASSISTED LAPAROSCOPIC NEPHRECTOMY IN A DONOR WITH TRIPLE RENAL VESSELS
}

\author{
Nefrectomia Laparoscópica Assistida pela Mão em Doador com Vasos Renais Triplos
}

Anibal Wood Branco', William Kondo ${ }^{2}$, Alexandre Bignelli ${ }^{3}$

\section{RESUMO}

Objetivo: A disponibilidade de doadores é um importante fator limitante para os programas de transplante renal; conseqüentemente, a equipe transplantadora deve estar apta a utilizar qualquer órgão, independente da anatomia vascular. Métodos: Relatamos um caso bem sucedido de nefrectomia vídeo-assistida em um doador de 69 anos com vasos renais triplos. A perda sangüínea estimada foi de $100 \mathrm{~mL}$, tempo cirúrgico de 80 minutos e o tempo de isquemia quente de três minutos. O transplante foi realizado na fossa ilíaca esquerda. O doador apresentou excelente evolução pós-operatória, recebendo alta no segundo dia após a cirurgia. O receptor recebeu alta hospitalar no oitavo dia de pós-operatório, com creatinina de 1,3mg\%. Discussão e Conclusão: Demonstramos qua a realização de nefrectomia video-assistida em um paciente com vasos renais triplos é factível, e compartilhamos da opinião que em mãos experientes, todos os procedimentos podem ser realizados por laparoscopia sem riscos adicionais para o doador e/ou receptor.

Descritores: laparoscopia, doadores vivos, nefrectomia, transplante, doadores marginais, múltiplas artérias.

Department of Urology and General Surgery, Cruz Vermelha Hospital, Curitiba, Paraná, Brazil.

1. Urologist from Cruz Vermelha Hospital

2. General Surgeon from Cruz Vermelha Hospital

3. Nephrologist from Cruz Vermelha Hospital

Endereço para correspondência: Dr. Anibal Wood Branco - Rua das Palmeiras, 170 ap. 201 - Curitiba - PR - Brasil - Zip Code 80620-210 - Fone: (55) (41) 242-6543 E-mail: anibal@awbranco.com.br

Recebido em: 04/07/05

\section{INTRODUCTION}

Because of the relatively limited donor supply compared to the large amount of patients with chronic renal failure, kidney allografts which were previously considered unsuitable for transplantation are now accepted for donation. ${ }^{1}$ These are called marginal donors, and are defined as not being optimum based on their age, as well as those presenting some kind of benign renal or nonrenal disease. ${ }^{2}$

One of major challenges in using marginal donors is the engraftment of kidneys with multiple renal arteries1 Due to anatomical and technical reasons, many transplant centers restricted laparoscopic donor nephrectomy in single-artery kidneys. ${ }^{3}$ Nevertheless, current advances in vascular surgical techniques, multiple or complicated renal arteries kidneys are now engrafted with no hesitation ${ }^{1}$. With increasing experience, laparoscopic donor nephrectomy in multiple renal artery cases has proved not to affect the donor or recipient outcomes. ${ }^{1,3-5}$

The aim of this article is to report a case of hand-assisted laparoscopic nephrectomy in a donor with triple renal vessels.

\section{CASE REPORT}

A 69 years old female donor sister of a 70 years old female recipient was submitted to preoperative standard immunologic and medical evaluation to confirm her suitability for kidney donation. An angiography revealed bilateral double renal arteries, and a renal scintigraphy with dimercaptosuccinic acid (DMSA) revealed a small worsening in the right side related to the renal function. Therefore, right donor nephrectomy was indicated.

The donor remained in a left lateral decubitus position on the operating table, and a 7-centimeter skin incision was performed in the right iliac fossa. The colon was medially reflected, and 
the ureter was identified. The Lap Disc ${ }^{\circledR}$ (Ethicon Endo-Surgery, Cincinnati, Ohio, USA) was placed through the incision, and the abdomen was inflated with carbon dioxide with 12 to $14 \mathrm{mmHg}$ intraabdominal pressure.

The trocars were placed: $10 \mathrm{~mm}$ in the periumbilical area for 30 degrees laparoscope; $10 \mathrm{~mm}$ halfway between the xiphoid and the umbilicus; $10 \mathrm{~mm}$ in the right middle axillary line at the umbilical level; $5 \mathrm{~mm}$ on the right side to retract the liver.

After the renal and ureteral dissection, the renal vessels were freed from the surrounding tissues. At this step of the surgery, it was noticed that the patient had triple renal artery and vein, instead of double renal vessels, as it had been demonstrated by the Angiography. Upon the analysis of her venous anatomy, she had two calibrous renal veins and a small superior one. Her arterial anatomy consisted to two small inferior polar arteries, and a superior calibrous one. All three branches of the artery and vein were dissected up to the aorta and inferior vena cava level, respectively (Figure 1). Throughout the operation, the urine output was monitored and maintained with fluids and mannitol.

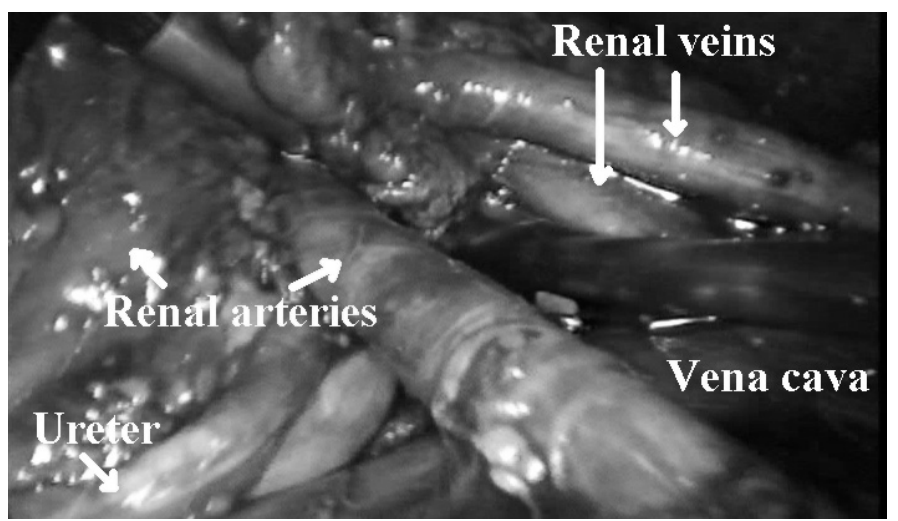

Figure 1. It can be observed one renal artery anteriorly crossing the vena cava, 2 renal veins and the ureter.

The ureter was connected using LT300 titanium clips (Ethicon Endo-Surgery), and after that, it was split up. The less calibrous vein was sacrificed being connected by clips and ager, and it was split. The main renal artery was connected using 2 clips, and the polar arteries were connected using one clip each, in order to not to increase the warm ischemia time.

The other renal veins were connected using 3 clips. All vessels were split up, and the kidney was retrieved from the cavity through the Lap Disc $^{\circledR}$ incision. The abdominal cavity was checked, and it was verified no kind of bleeding. Next an additional clip was placed in each polar renal artery. The estimated blood loss was of $100 \mathrm{~mL}$, the operative time was of 80 minutes, and the warm ischemia time was of 3.0 minutes.

The renal allograft was delivered on the back table and placed in an ice slush box. All arteries were perfused using cold Ringer lactate solution. The renal vessels were cleaned off of hilar fat. Using a 7-0 prolene continuous suture, one-third of the adjacent circumference of both inferior renal arteries - the less calibrous - were sutured together.

Both renal veins were sutured together using the same technique. The transplant was performed in the left iliac fossa (Figure 2). One opening was made in the external iliac artery to anastomose the arterial common channel, and another arteriotomy was made for the main renal artery. The common vein was anastomosed to the external iliac vein thorugh a single venotomy. The ureter was implanted using the LichGregoire technique with a double pigtail stent placed in situ.

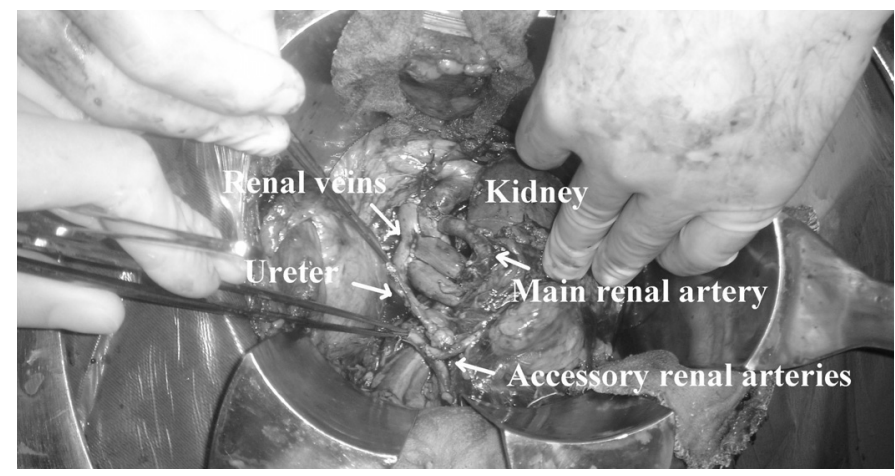

Figure 2. Surgical implantation of the graft through an extraperitoneal incision in the left iliac fossa.

The donor experienced an uneventful recovery, and she was discharged on the second postoperative day. The recipient was discharged home on the 8th postoperative day, and her creatinine level was of $1.3 \mathrm{mg} \%$.

A follow-up for the next 5 months was done, and the patient had no surgical complications or rejection, and her latest creatinine level was of $0.9 \mathrm{mg} \%$.

\section{COMMENTS}

Lately, many centers have been reluctant to use kidneys with multiple arteries, especially when other promising conditions exist, such as donor age and long cold ischemia time, due to the fear of technical complications and graft loss 6 . Theoretically, multiple renal arteries are more likely to lead to technical difficulties during the anastomosis with an increased incidence of arterial stenosis and thrombosis ${ }^{7}$. Aiming the fact that approximately $30 \%$ of kidneys have multiple renal arteries $4,5,8$ and $10 \%$ of such anomaly are bilateral, many good grafts are lost if these kidneys are discarded. ${ }^{4}$

A recent experience done by several centers has shown that the aforementioned theoretical problems can be avoided with good surgical techniques, and excellent graft survival can be attained. ${ }^{1,3-5}$

The Organ Transplantation Unit from the Tepecik Hospital ${ }^{3}$ compared 31 nephrectomies performed via laparoscopy, being eight with multiple arteries, and 84 using open approach, and nine being with multiple arteries concluded that the laparoscopic donor nephrectomy is as safe as an the open surgery, even upon the presence of multiple renal arteries, and being done by the most renowned transplant surgeons team.

In a review of 1011 living related transplants, the Sanjay Gandhi Post Graduate Institute of Medical Sciences group 2 revealed 82 older than 60 years donors and 104 donors associated to renal or nonrenal anomalies or disease. They stated that the refusal of marginal donors would have promoted unrelated transplantation or forced lifelong dialysis in $18.2 \%$ of their patients.

As result, healthy donors should not be rejected based on their age or presence of renal or nonrenal anomalies, whenever they can be treated without compromising the donor or recipient safety.

The Mansoura University group 1 analyzed 1200 consecutive 
living donor renal transplants, including 113 with multiple arteries. They observed that the multiplicity of renal arteries had no negative impact on the graft survival, and there was no association between multiplicity of the renal artery and the increased risk of vascular complications. Ischemia time was significantly longer in the multiple artery group than in the single artery group; however, it was not reflected on the incidence of acute tubular necrosis. A higher mean serum creatinine was noted in one year in multiple arteries than in the single artery group, but it was not maintained in 5 years.

Several surgical and microsurgical techniques of intracorporeal and ex vivo surgeries have been used to implant kidneys with multiple arteries. ${ }^{5,7,9}$ The advantages, disadvantages and the outcome of ex vivo and intracorporeal anastomotic techniques are not clearly defined up to this moment.1 In situ techniques include the use of various branches of the recipient hypogastric artery, a combination of hypogastric and external iliac arteries, multiple individual endto-side anastomoses to the external iliac artery, and even the inferior epigastric artery ${ }^{7,10}$. On the other hand, the main objective of the $e x$ vivo microvascular techniques 11 is to create a single arterial ostium to facilitate the in situ vascular anastomosis with maximal accuracy and minimal warm ischemic damage to the kidney. Nevertheless, some authors believe that these more complex reconstruction techniques may not be necessary for the wide majority of all laparoscopically procured multiple renal artery grafts. ${ }^{8}$

The Tokyo Women's Medical University group ${ }^{5}$ made a retrospective review of patients with multiple renal artery reconstruction in kidney transplantation. When the two renal arteries weren't close to each other, conjoined anastomosis or end-to-side anastomosis were used. When the two arteries were not close enough to each other to use the previous techniques, reconstruction with autogenous arterial grafts or multiple anastomoses was performed. All these methods were performed extracorporeally under hypothermia. The allograft was transplanted as being a single artery, with no additional warm ischemic time. The advantages of these methods are that they demand no added warm ischemic time, and they allow a precise extracorporeally performed anastomosis with optimal exposure and illumination. On the other hand, using the multiple anastomosis method performed in situ, they occasionally found poor visibility and suturing difficulty. Due to these reasons, they prefer the extracorporeal reconstruction rather than using the multiple anastomosis method5. Differences were statistically noticed between the reconstructed $(n=44)$ and nonreconstructed $(\mathrm{n}=290)$ groups in total ischemic times and incidence of post-transplantation hypertension, but not in the creatinine levels or acute rejection rates.

In our patient, we performed a conjoined anastomosis for the two smaller renal arteries, and the main renal artery had a single revascularization.

In this article, we could demonstrate the feasibility of hand-assisted laparoscopic nephrectomy in a patient with triple renal vessels, and we share the opinion that in experienced hands, all procedures can be done by laparoscopy with no additional risk to the donor and/or the recipient.

\section{ABSTRACT}

Objective: Donor availability is an important limiting factor in renal transplant programs; consequently, it is important to be able to use every vital organ independent of the vascular anatomy. Method: It is reported a successful case-story of hand-assisted laparoscopic nephrectomy in a 69-year-old related donor with triple renal vessels. The estimated blood loss was of $100 \mathrm{~mL}$, the operative time was of 80 minutes and the warm ischemia time was of 3.0 minutes. The transplant was performed in the left iliac fossa. The donor experienced an excellent recovery, and she was discharged in the second postoperative day. The recipient was discharged home in the ${ }^{8 \text { th }}$ postoperative day, and her creatinine level was of $1.3 \mathrm{mg} \%$. Discussion and Conclusion: It was demonstrated the feasibility of hand-assisted laparoscopic nephrectomy in a patient with triple renal vessels, and we also share the opinion that in experienced hands, all procedures can be done by laparoscopy with no additional risk to the donor and/or the recipient.

Key-words: laparoscopy, living donors, nephrectomy, transplantation, marginal donors, multiple arteries.

\section{REFERENCES}

1. Ali-El-Dein B, Osman Y, Shokeir AA, Shehab El-Dein AB, Sheashaa H, Ghoneim MA. Multiple arteries in live donor renal transplantation: surgical aspects and outcomes. J Urol 2003; 169: 2013-7.

2. Kumar A, Das SK, Srivastava A: Expanding the living related donor pool in renal transplantation: use of marginal donors. Transplant Proc 2003; 35: 28-9.

3. Gurkan A, Kacar S, Basak K, Varilsuha C, Karaca C. Do multiple renal arteries restrict laparoscopic donor nephrectomy? Transplant Proc 2004; 36: 105-7.

4. Ganesan KS, Huilgol AK, Sundar S, Chandrashekar V, Prasad S, Raviraj KG. Management of multiple arteries in renal transplantation. Transplant Proc 1994; 26 : 2101-2.

5. Makiyama K, Tanabe K, Ishida H, Tokumoto T, Shimmura H, Omoto K, et al. Successful renovascular reconstruction for renal allografts with multiple renal arteries. Transplantation 2003; 75: 828-32.
6. Perico N, Ruggenenti P, Scalamogna M, Remuzzi G. Tackling the shortage of donor kidneys: how to use the best that we have. Am J Nephrol 2003; 23: 245-59.

7. Benedetti E, Troppmann C, Gillingham K, Sutherland DE, Payne WD, Dunn DL, et al. Short- and long-term outcomes of kidney transplants with multiple renal arteries. Ann Surg 1995; 221: 406-14.

8. Troppmann C, Wiesmann K, McVicar JP, Wolfe BM, Perez RV. Increased transplantation of kidneys with multiple renal arteries in the laparoscopic live donor nephrectomy era: surgical technique and surgical and nonsurgical donor and recipient outcomes. Arch Surg 2001; 136: 897-907.

9. Miura M, Seki T, Harada H, Chikaraishi T, Nonomura K, Koyanagi T. Clinical evaluation of donor renal artery reconstruction in kidney transplantation. Transplant Proc 1996; 28: 1611-3.

10. Han D, Choi S, Kim S. Microsurgical reconstruction of multiple arteries in renal transplantation. Transplant Proc 1998; 30: 3004-5.

11. Novick AC. Microvascular reconstruction of complex branch renal artery disease. Urol Clin North Am 1984; 11: 465-75. 